\title{
Erratum to: Use of almond shell as food ingredient
}

\author{
Imen Kacem ${ }^{1} \cdot$ Nuria Martinez-Saez $^{2} \cdot$ Fatma Kallel $^{1} \cdot$ Khawla Ben Jeddou $^{1}$ • \\ Claire Boisset Helbert ${ }^{3} \cdot$ Semia Ellouze Chaabouni ${ }^{1,4} \cdot$ Maria Dolores del Castillo ${ }^{2}$
}

Published online: 26 June 2017

(C) Springer-Verlag GmbH Germany 2017

\section{Erratum to: Eur Food Res Technol \\ DOI 10.1007/s00217-017-2912-4}

The given name and family name of fourth, fifth and sixth authors were incorrectly published in the original publication. The correct given name and family name should read as follows:

Khawla Ben Jeddou Claire Boisset Helbert

Semia Ellouze Chaabouni

The original article has been updated.

The online version of the original article can be found under doi:10.1007/s00217-017-2912-4.

Maria Dolores del Castillo

mdolores.delcastillo@csic.es

http://www.cial.uam-csic.es

Nuria Martinez-Saez

http://www.cial.uam-csic.es

1 Enzymes and Bioconversion Unit, National Engineering School, Sfax University, P.O. Box 1173-3038, Sfax, Tunisia

2 Institute of Food Science Research (CIAL, UAM-CSIC), C/Nicolás Cabrera, 9. Campus de Cantoblanco. Universidad Autónoma de Madrid, 28049 Madrid, Spain

3 Service de Chromatographie Purification et analyse de polysaccharides CERMAV-CNRS, 601 rue de la Chimie, 38041 Grenoble Cedex 9, France

4 Common Service Unit of Bioreactor Coupled with an Ultrafilter, National Engineering School, Sfax University, P.O. Box 1173-3038, Sfax, Tunisia 